\title{
ФИНАНСОВО-КРЕДИТНАЯ СФЕРА
}

UDC 336.748

\author{
M.N. Koniagina
}

\section{DYNAMICS OF BANK DEPOSITS IN 2014-2015 UNDER CONDITIONS OF FLUCTUATIONS IN THE RUSSIAN RUBLE EXCHANGE RATE: ANALYSIS AND INTERPRETATION}

The Russian monetary system has been repeatedly influenced by many negative factors, the last of which was the 2014 devaluation of the ruble, a key element of the national monetary system. This resulted from a change in the Bank's policy on exchange rate setting and new monetary decisions. At the same time, estimates by various analysts and representatives of the Ministry of Finance, Central Bank, and other official bodies and agencies are ambiguous and often cause confusion among ordinary citizens. The presentation and interpretation of dynamics of some money market indicators in the mass media, as resulting from Central Bank decisions, necessitates the study and application of such tools that produce unambiguous results. The main goal of this article is to study dynamics of bank deposits and exchange rates for the Russian ruble, Euro, and US dollar, to ascertain if dynamics of bank deposits in Russia reflect changes in public confidence in the national currency for mid-2014 the beginning of 2016. The study uses methods of comparative analysis, including graphic representation, consolidation, and correlation analysis, methods verified by Russian and foreign economists, of large data within a certain timeframe. Refs 19. Figs 6.

Keywords: bank deposit, currency rate, devaluation, monetary policy, national currency, foreign currency.

\section{М. Н. Конягина \\ ДИНАМИКА БАНКОВСКИХ ДЕПОЗИТОВ В УСЛОВИЯХ КОЛЕБАНИЙ КУРСА РУБЛЯ В 2014-2015 ГГ.: АНАЛИЗ И ИНТЕРПРЕТАЦИЯ}

Российская денежная система многократно испытывала на себе влияние негативных факторов. Последним ярким событием для граждан России в отношении рубля - основного элемента денежной системы страны - стала его девальвация во второй половине 2014 г., связанная с изменением подхода Банка России к установлению курса национальной валюты и новыми решениями в области денежно-кредитной политики. Население испытало на себе множество негативных последствий этого события. Одновременно оценки аналитиков, представителей Министерства финансов, Центрального банка и иных органов и ведомств неоднозначны и часто вызывают недоумение у простых граждан. Такое неоднозначное понимание и интерпретация динамики отдельных показателей денежного рынка в средствах массовой

Maria N. KONIAGINA - Doctor in Economics, Professor, Saint Petersburg State University of Economics, 191023, St. Petersburg, 21 Sadovaya Str., Russia; a070278@yandex.ru

Мария Николаевна КОНЯГИНА - доктор экономических наук, профессор, СанктПетербургский государственный экономический университет, Российская Федерация, 191023, Санкт-Петербург, ул. Садовая, 21; a070278@yandex.ru

(C) Санкт-Петербургский государственный университет, 2017 
информации вследствие решений Банка России вызвали необходимость разъяснения данного вопроса на основе проведения исследования с применением инструментария, результаты которого могут быть однозначно истолкованы. Целью изучения динамики банковских вкладов и курсов российского рубля, евро и доллара США является поиск ответа на вопрос: отражает ли динамика банковских вкладов в России изменение доверия населения к национальной валюте в период со второй половины 2014 г. до начала 2016 г.? В статье используются методы сравнительного анализа, включающие графическую визуализацию, обобщение и корреляционный анализ, примененные для массива данных в рамках обозначенного временного периода и многократно оправдавшие себя в работах отечественных и зарубежных ученых-экономистов. Библиогр. 19 назв. Ил. 6.

Ключевые слова: банковский вклад, валютный курс, девальвация, денежно-кредитная политика, национальная валюта, иностранная валюта.

\section{Introduction}

During the period of geopolitical instability and disapproved position of Russia in the international financial market, the government considered domestic sources to finance economy and investment. It was expected that, in return for long-term support and favorable conditions created for the banking sector, it would redirect the temporarily free funds into the national economy. However, there were mixed views about the amount of resources accumulated by the Russian banks and their investment into economy. For example, in the second half of 2015 - beginning of 2016 a number of practicing economists - Russian analysts, representatives of state corporations and governmental agencies - made some ambiguous statements during official events. Here we shall cite some of them.

"Deposits from the population had been increasing faster than expected until December 2015 and forecasts made by the regulatory authority and major banks had to be revised upwards. In the beginning of the year, growth forecast was at 5-8\%, then the Central Bank announced $10 \%$ growth, now, at the end of 2015 , the baseline forecast is $15 \%$. This is higher than the level of inflation which, according to the Ministry for Economic Development, shall reach $12.7-12.8 \%$.

However, we anticipate that even despite the expected the rate growth in December..., individual deposit growth rates would slow down significantly. Foreign currency deposits would continue to grow, while ruble deposits would decrease and this trend is to continue in January. Deposits for one year with the highest rates, which increased their share in the deposits made by the population in December last year, could have been maintained should the population be more optimistic about macroeconomic stability and exchange rates, as well as inflation" [Deposits of the Population..., 2015].

"During the first five months of 2015 Russian depositors brought 830 billion rubles into the banking system, which increased the deposit base by almost $7 \%$ ", said Andrej Melnikov, deputy director general of the state corporation "Deposit Insurance Agency" (DIA), at the XVI Russian national banking forum in Nizhny Novgorod. According to Melnikov, "deposits have demonstrated such dynamics for the first time in the past two years". He added that "the amount of deposits has increased despite the shocks which happened over this time" [DIS: Russians for ..., 2015].

Such claims, made many times, could not but raise professional curiosity and demand verification. In order to do this statistical data, provided by the Central Bank site, was used [The Central Bank of Russian Federation, 2016]. The working hypothesis is that, despite the nominal growth of bank deposits in 2014-2015, real growth rate was rather low. It doesn't permit the conclusion that Russians trust the ruble as a currency for making savings. More 
than that, the decision of the Central Bank about devaluation of national currency as a part of the national monetary policy has led to the impoverishment of the population, and statistical increase in the volume of foreign currency deposits as a result of currency conversions is interpreted in the wrong way by economists. The basic premise is that since 2013 the Russian economy has been affected by political instability, economic crisis, and then by western sanctions in 2014. Banks have lost the opportunity to borrow on the international market and had to explore domestic resources. However, inflation and devaluation of the national currency has led to a significant decrease in the spending capacity of the population. In this connection, it may be assumed that the amount of ruble deposits should either remain unchanged or decrease. Besides that, in 2014-2015 the ruble sharply depreciated and for individual bank clients it would have been more beneficial to convert ruble deposits into foreign currency ones. Therefore, there is a high probability that an instable economy leads to the loss of confidence in the national currency.

\section{Theoretical background}

It should be noted that the subject of bank deposits as financial resources on the micro and macro level has been of little interest to national economists. In 2015-2016 it was studied by N. I. Valentseva, E. S. Cosco, D. D. Polikarpov, A. I. Kipkeeva [Valentseva et al., 2016], S. V. Anureev [2015], A. V.Egorov, E. N. Chekmareva, I. A. Voronova [Egorov et al., 2016], with dissertation papers presented by L. A. Vinokurova [2016] and S. A. Bondareva [2016]. Only the latter study provides a comparative analysis of bank deposit portfolios and further investment of accumulated resources.

Another important issue is the influence of foreign currency, mainly the Euro and the US dollar, on the size and structure of the aggregate deposit portfolio. Only few authors raised this subject in the leading national publications in the past decade, including S.V. Anureev [2015] and E. E. Rumiantseva [2009], who studied depositors' behavior during the instability of foreign exchange rates, difference between real and nominal income of depositors and its implications for the economy. S.K. Semionov [2007] talks about the negative consequences of the dollarization of the economy, echoing the studies conducted by M. Savastano [1996], R. Chang, A. Velasco [Chang, Velasco, 2002], E. Feige [2002a; 2002b], A. Shinkevich, N. Oomes [Shinkevich, Oomes, 2002] and other scholars. U. A. Haritonova [2011] examined another aspect of this subject - the possibility of economic stimulation through exchange rates, where she applies ideas of M. Fleming [1962], R. Mundell [1963] and J.Williamson [1983(1985)], which continue to be relevant nowadays.

Nevertheless, the problem rose in this article, while being aligned with the fundamental ideas of western economists and practical studies of national specialists, has its own way for development - narrower and more practical, based on the popular econometric modeling technique.

To verify the hypothesis, it was decided to use the method of comparative analysis which involves graphs, consolidation and correlation analysis.

The aim of this article is to study the interrelation between currency rates (ruble, US dollar and euro) and the dynamics of private foreign and national currency deposits in Russia. To reach this aim, there are the following objectives:

- to study the dynamics of private deposits in national and foreign currency in Russia; 
- to examine the dependency between foreign currency deposits and foreign currency rates (US dollar and Euro);

- to study the behavior of the depositor and determine if it depends on changes in currency rates.

First, there is a need to examine changes in private ruble and foreign currency deposits.

From 01.01.2014 till 01.01.2016 ruble deposits increased by 13.5\% (from 13985238 to $15879147 \mathrm{mln}$ rub.), while foreign currency deposits, denominated in foreign currency, grew only by $2.66 \%$. Nevertheless, it should be noted the growth rate of foreign currency deposits denominated in rubles was over $136 \%$.

Now, let's consider the causes of the changes in more detail, starting with foreign currency deposits.

There are two factors that might have affected these deposits:

- conversion of private ruble deposits into foreign currency;

- rubles weakening.

The first depositor's choice, i. e. withdrawal of money from rubles deposits and converting it into foreign currency deposits, would have been the most rational. For example, 100000 rubles deposited for the period from 30.08.2014to 01.02 .2016 at $8.02 \%$ for 1.5 years would have brought a profit of 12090 rub. $01 \mathrm{kop}$., while timely conversion into US dollars and opening a foreign currency deposit for the same period at $3.08 \%{ }^{1}$ would have brought 10 times higher profit of 116226 rub. 48 kop.

It's interesting to note that there is no simultaneous positive dynamics of foreign currency deposits and negative dynamics of rubles deposits (fig. 1).

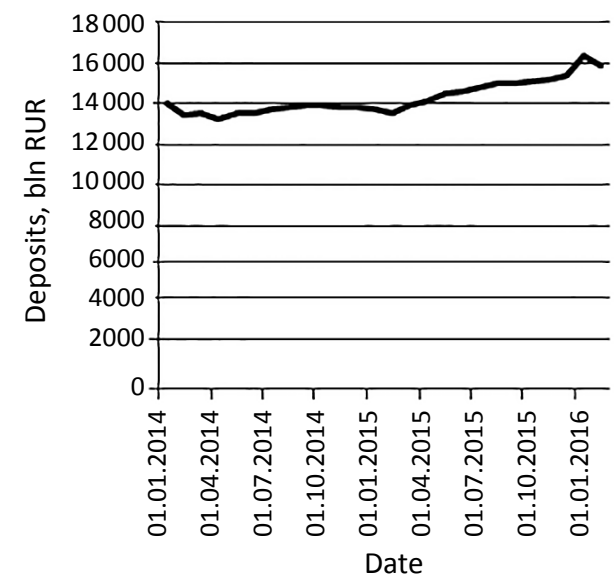

a) Aggregate rubles

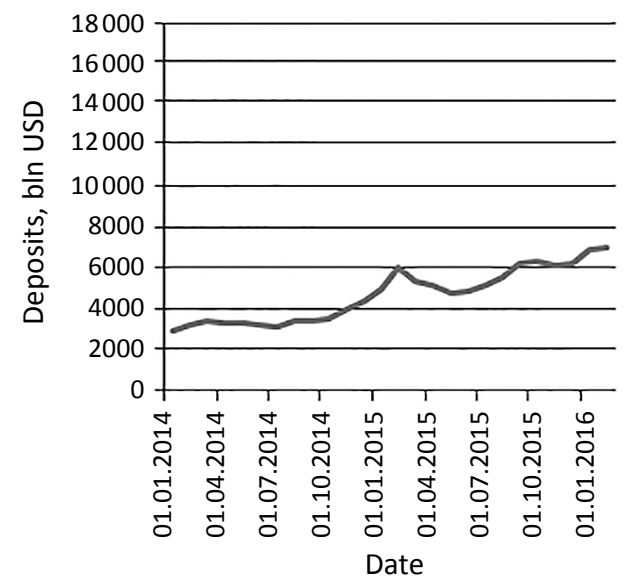

b) Foreign currency deposits

Figure 1. Dynamics of aggregate rubles and foreign currency deposits in the Russian banking system (01.01.2014-01.02.2016)

S o u r ce: The Central Bank of the Russian Federation, 2016. URL: http://cbr.ru/ (accessed: 22.01.2017).

\footnotetext{
${ }^{1}$ Information on deposits of individuals and non-financial organizations in rubles, US dollars and Euros of the Central Bank of the Russian Federation. Available at: http://www.cbr.ru/statistics/?PrtId=int_ rat (accessed: 05.12.2016).
} 

nificant.

Deposit dynamics shows that should the conversion occur, it would have been insig-

The second factor affecting the deposit dynamics of foreign currency deposits, namely the foreign currency rates, suggests otherwise. The majority of foreign currency deposits in Russian banks are deposits in Euros and US dollars. According to the Bank of Russia (see fig. 2 and 3), both currencies show similar trends.

Despite temporary growth of the euro against the US dollar, the rate difference against the ruble was insignificant. It is necessary, therefore, to focus on the interdependence between the amount of foreign currency deposits and US dollar rates, as the US dollar is the currency that is traditionally preferred by Russian citizens, partly due to the negative processes taking part in the EU economy during the period of study.

To determine the extent to which foreign currency deposits depend on US dollar rates, we should calculate the correlation co-efficient (formula 1).

$$
r_{x y}=\frac{\sum(X-\bar{X})(\boldsymbol{Y}-\overline{\boldsymbol{Y}})}{\sqrt{\sum(\boldsymbol{X}-\overline{\boldsymbol{X}})^{2} \sum(\boldsymbol{Y}-\overline{\boldsymbol{Y}})^{2}}} ;
$$

where $\bar{X}=\frac{1}{n} \sum_{t=1}^{n} X_{t} ; \bar{Y}=\frac{1}{n} \sum_{t=1}^{n} Y_{t}-$ average for the sample.

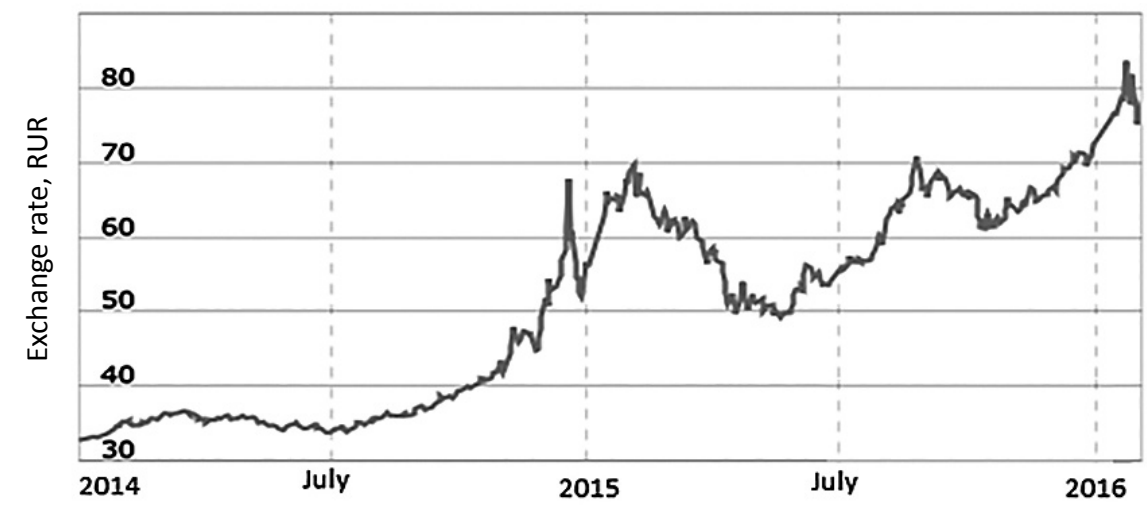

Figure 2. The evolution of the US dollar exchange rate against the ruble (01.01.2014-01.02.2016) S ource: The Central Bank of the Russian Federation, 2016. URL: http://cbr.ru/ (accessed: 22.01.2017).

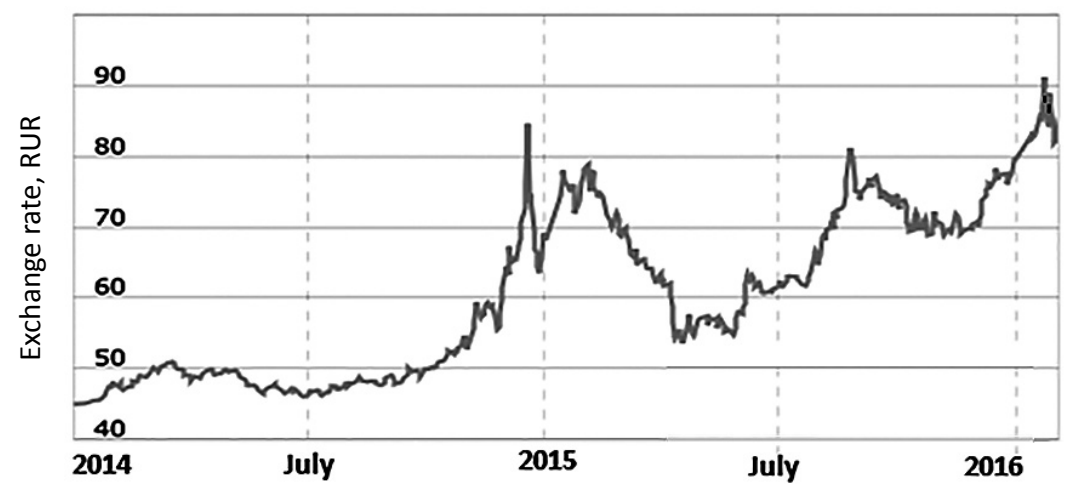

Figure 3. The evolution of the euro exchange rate against the ruble (01.01.2014-01.02.2016)

S o u r ce: The Central Bank of the Russian Federation, 2016. URL: http://cbr.ru/ (accessed: 22.01.2017). 
The correlation co-efficient shows how these indicators change and the level of interdependency. It may range from -1 to 1 . A value close to 1 is a positive indicator, which means strong correlation and direct dependence between these factors. In such case, the increase of one of the factors, e.g. US dollar rate, leads to the increase of the outcome indicator - amount of the deposits denominated in US dollars, and vice versa. A value close to -1 shows negative correlation and inverse dependence between these factors, when the increase in the monitored factor leads to the decrease of the outcome indicator to the same degree. Values near zero show weak correlation and low level of interdependence between factors, which means that the change in the monitored factor does not lead to the change in the outcome indicator.

The correlation analysis has demonstrated strong dependence between the exchange rate of the US dollar and the increase in foreign currency deposits, as it is shown by the correlation co-efficient of 0.99 . Also, we can observe similarity in the graphs showing changes in foreign currency deposits and the US dollar rates (fig. 4).

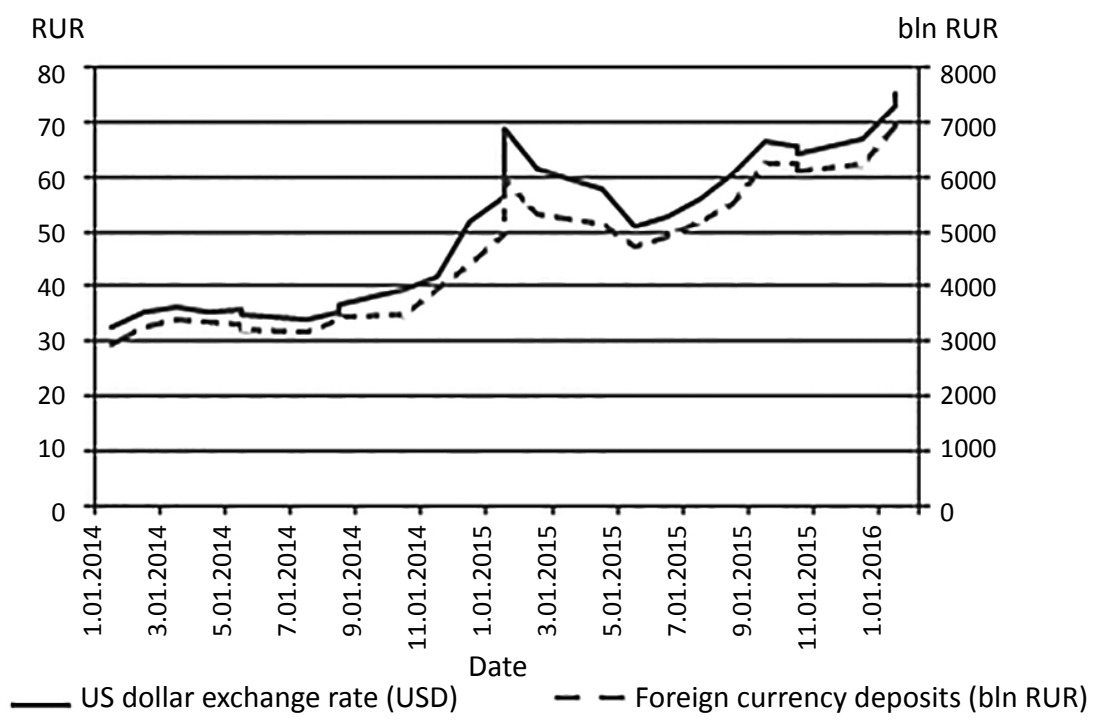

Figure 4. Dependency between the volume of foreign currency deposits in Russian banks and the US dollar rate (01.01.2014-01.01.2016)

S o u r ce: The Central Bank of the Russian Federation, 2016. URL: http://cbr.ru/ (accessed: 22.01.2017).

Bearing in mind that it was the Bank of Russia's statistics that provided the data for the analysis, it is obvious that the real amount of foreign currency deposits has demonstrated very little change, which is so insignificant that graphs show only the changes resulting from the conversion of deposits denominated in foreign currency. $13.6 \%$ increase in ruble deposits might be accounted for by the increase of the Central Bank's base rate and, as a result, of commercial bank deposit rates (fig. 5).

It seems that by the end of 2014 the volume of ruble deposits should have increased following the increase in interest rates, but the actual situation was quite the contrary (fig. 6). There might be several reasons for this: either depositors chose to follow a waitand-see strategy in anticipation of changes on the currency and deposit markets, or they just did not have enough available funds. Another reason is that depositors realized that they had suddenly become much poorer and decided to hold on their cash. 


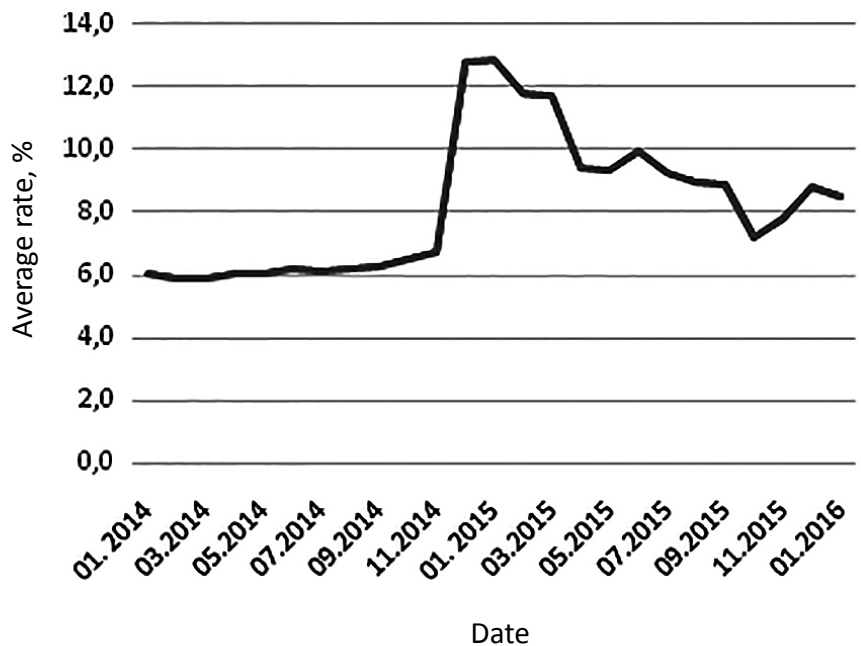

Figure 5. Dynamics of average rate on ruble deposits for a term up to one year, excluding demand deposits, in the Russian banks (01.01.2014-01.02.2016)

So u rce: The Central Bank of the Russian Federation, 2016. URL: http://cbr.ru/ (accessed: 22.01.2017).

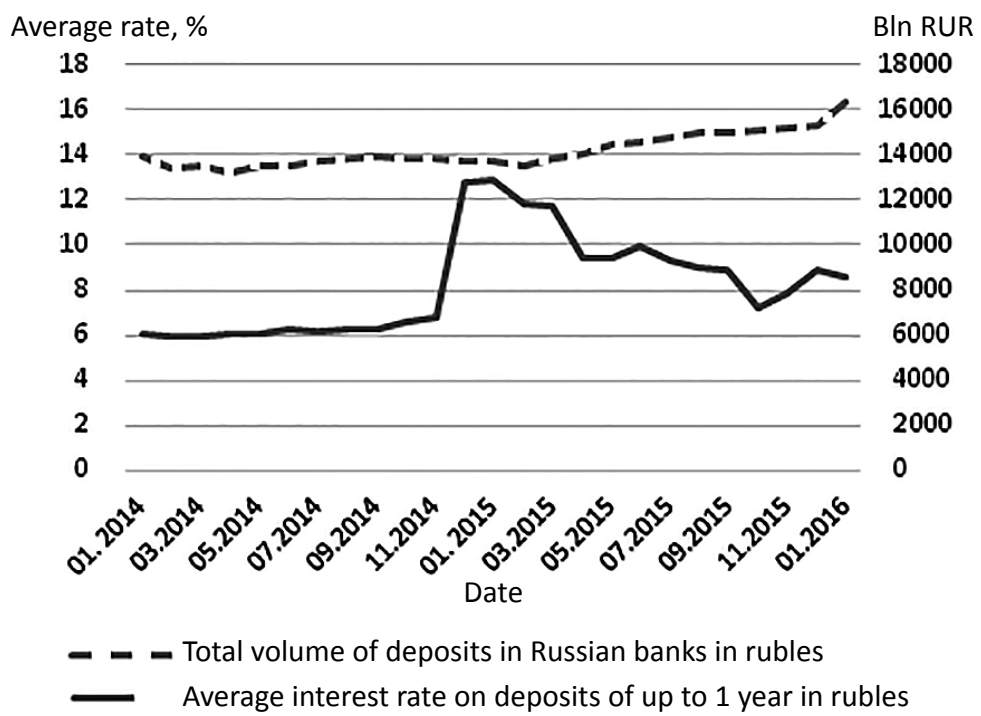

Figure 6. Dynamics of average rate on ruble deposits for a term up to one year, excluding demanded deposits, and total volume of ruble deposits in the Russian banks (01.01.2014-01.02.2016)

S o u r ce: The Central Bank of the Russian Federation, 2016. URL: http://cbr.ru/ (accessed: 22.01.2017).

The deposit dynamic starts to demonstrate a positive trend and becomes independent from the average rate changes from 01.01.2015until 01.02.2016. It can be explained by the following factors:

- firstly accrued interest on extended deposits, i. e. bank clients chose not to withdraw money, by, but to capitalize interest accumulated on their deposits;

- secondly, by the amendments to the Federal Law № 177-Ф3 (Federal Act) "On the insurance of private deposits in the banks of the Russian Federation" of 23 December 2003, which came into force on 29 December 2014 and according to which 
the amount of money paid to the depositor in case of insured event was doubled (from 700000 rub. to 1400000 rub.). It led to an increase in the confidence in banks, even though it could hardly be called proportionate.

In other words, the most important factors contributing to the increase in the aggregate private deposit portfolio in banks have become the increased insurance on deposits and the effect of the "silent depositor", who is unaware of or expects clear signals from the market.

Interdependence between ruble deposits and foreign currency rates (US dollar) turned out to be weak, as it is proved by their low correlation. However, the following fact demands attention: in the end of January 2015, when the US dollar rate was increasing, ruble deposits were decreasing, while foreign currency deposits showed an insignificant increase, which proves that some part of ruble deposits might have been converted into foreign currency.

\section{Conclusion}

The study of the dynamics of private ruble and foreign currency deposits in Russia identified a variation in trends depending on the foreign exchange rates, national insurance scheme and market expectations. The correlation analysis not only proved the supposed dependency between the foreign currency deposits and US dollar rates, but also showed that it has little influence on the volume of private deposits denominated in rubles.

On that basis, we can conclude that there is no direct relationship between the volume of private deposits denominated in rubles and the national currency rate and, thus, there are grounds to say that the Russian ruble can hardly perform the function of saving currency. Or it is the depositors who failed to respond to the changes in the money market structure due to rapid impoverishment after devaluation. It disproves the statements made by some speakers to the mass media that the population managed to adapt to the changes on money market. Faulty impression about the sharp aggregate private deposit growth is produced by the automatic conversion of some private foreign currency deposits, the share of which was lower that the share of ruble deposits, in current currency rates for interim and annual financial reporting of banking institutions.

Speaking about the confidence of Russians in the national currency, it is hardly reflected by the change in the volume of deposits, but it demonstrates the expectations for clearer signals, a wait-and-see tactics and a lack of information about the opportunities for the depositors in commercial banks to convert ruble deposits into foreign currency (the majority of depositors were unaware of such options rather than unwilling to do it). The depositors, however, were well-informed about the protection of deposits under the National insurance scheme.

The study on the interdependence between the ruble, US dollar and Euro rates and the dynamics of private deposits denominated in corresponding currencies in Russia identified a number of omissions made in the publications by practicing economists, confirmed the findings by E. E. Rumiantseva [2009] and S. V. Anureev [2015] about the prevailing number of private depositors and their impoverishment and proved the hypothesis of the author of this article. It also revealed some differences, which are mostly likely to be accounted for by the time period between the studies, in the behavior of depositors in emerging economies as described by foreign researchers [Honohan, Anqiing, 2002; Shinkevich, Oomes, 2002]. 


\section{References}

Anureev S. V. Professional Depositors - Profit Recorders and the Bank's Interest Rate Risks. Money and Credit, 2015, no. 6, pp. 51-55. (In Russian)

Bondareva S. A. Development of Personal Finances in Modern Conditions. Abstract of PhD thesis in Economics. Moscow, 2016. 25 p. (In Russian)

Chang R., Velasco A. Dollarization: Analytical Issues. NBER Working Paper, 2002, no. 8838. Available at: http:// www.nber.org/papers/w8838.pdf (accessed: 05.12.2016).

DIS: Russians for five months of 2015 have brought to the banks 830 billion rubles. The Association of Russian Banks, Financial Sector News on July 2, 2015. Available at: http://arb.ru/b2b/news/asv_rossiyane_za_pyat_ mesyatsev_2015_goda_prinesli_v_banki_830_mlrd_rubley-9928308/?sphrase_id=211352 (accessed: 05.12.2016). (In Russian)

Egorov A. V., Chekmareva A. V., Voronova B. A. Adaptation of Russian Banks to the Economic Turbulence. The Banking, 2016, no. 1, pp. 6-10. (In Russian)

Feige E.L.Dollarization and Euroization in Transition Countries. Working Paper of Fordham University International Conference on "Euro and Dollarization: Forms of Monetary Union in Integrating Regions", 2002a, April. Available at: https://econpapers.repec.org/paper/wpawuwpif/0205003.htm (accessed: 05.12.2016).

Feige E. L. Empirical Evidence on Currency Substitution, Dollarization, and Euroization in Transition Countries: The 8th Dubrovnik Conference on Monetary Policy and Currency Substitution in Emerging Markets, 2002b, June. Available at: https://www.hnb.hr/en/-/14th-conferen-4 (accessed: 05.12.2016).

Fleming M. J. Domestic Financial Policies Under Fixed and Under Floating Exchange Rates. IMF Staff Papers, 1962, November, vol. 9. Available at: https://econpapers.repec.org/article/palimfstp/v_3a9_3ay_3a1962_3a i_3a3_3ap_3a369-380.htm (accessed: 05.12.2016).

Haritonova U. A. Using the exchange rate to stimulate the economies of the developed countries: problems and contradictions. Finance and Credit, 2011, no. 13 (445), pp.67-71. (In Russian)

Honohan P., Anqiing Sh. Deposit Dollarization and the Financial Sector in Emerging Economies. Development Research Group The World Bank, 2002. Available at: http://citeseerx.ist.psu.edu/viewdoc/download?doi=10 .1.1.199.3856\&rep=rep1\&type=pdf (accessed: 05.12.2016).

Mundell R. A. Capital Mobility and Stabilization Under Fixed and Flexible Exchange Rates. Canadian Journal of Economics and Political Science, 1963, November, vol.29, no.4. Available at: http://pages.stern. nyu.edu/ dbackus/GE_asset_pricing/Mundell\%20MacLeod\%20comment\%20on\%20CJE\%2064.pdf (accessed: 05.12.2016).

Deposits of the Population: the limits to growth: Analytical review of NAFI-Center on $22^{\text {nd }}$ of December, 2015. The Oficialweb-siteof NAFI-Center. Available at: https://nafi.ru/analytics/(accessed: 05.12.2016)

Rumiantseva E. E. Population Losses in the Financial Crisis in Russia. Finance and Credit, 2009, no. 17 (353), pp. 17-21. (In Russian).

Savastano M. Dollarization in Latin America: Recent Evidence and Some Policy Issues. IMF Working Paper, 1996, January, no. 4. Available at: http://www.imf.org/external/pubs/ft/op/238/pdf/op238_6.pdf (accessed: 05.12.2016).

Semionov S. K. Money: dollarization as an inflation factor. Finance and Credit, 2007, no. 30 (270), pp.47-51. (In Russian)

Shinkevich A., Oomes N. Dollarization Hysteresis in Russia. EERC Working Paper, 2002. January. Available at: http://pdc.ceu.hu/archive/00002002/01/00-087e.pdf?origin\%3Dpublication_detail (accessed: 05.12.2016).

Valentseva N.I., Cosco E.S., Polikarpov D.D., Kipkeeva A.I. The Development of the Traditional Activities of the Commercial Banks as a Condition of Their Financial Stability. The Banking, 2016, no. 7, pp. 63-69. (In Russian)

Vinokurova L. A. The Resource Potential of the Population to Improve the Competitiveness of Commercial Banks. Abstract of PhD thesis in Economics. Moscow, 2016. 25 p. (In Russian)

Williamson J. The Exchange Rate System. Washington: Institute for International Economics, 1983 (revised in 1985). $85 \mathrm{p}$.

For citation: Koniagina M.N. Dynamics of bank deposits in 2014-2015 under conditions of fluctuations in the Russian ruble exchange rate: Analysis and interpretation. St Petersburg University Journal of Economic Studies, 2017, vol. 33, issue 4, pp. 593-601. https://doi.org/10.21638/11701/spbu05.2017.404. 